\title{
OVIPOSITION BEHAVIOUR OF Gryon gallardoi (HYM.; SCELIONIDAE) ON EGGS OF Spartocera dentiventris (HEM.; COREIDAE)
}

\author{
WIEDEMANN, L. M., ${ }^{1}$ CANTO-SILVA, C. R., ${ }^{2}$ ROMANOWSKI, H. P. ${ }^{1,2}$ \\ and REDAELLI, L. R. ${ }^{2,3}$ \\ ${ }^{1}$ Departamento de Zoologia da UFRGS, Av. Bento Gonçalves, 9500, Porto Alegre, RS \\ ${ }^{2}$ PPG Biologia Animal, UFRGS, Av. Bento Gonçalves, 9500, CEP 91501-970, Porto Alegre, RS \\ ${ }^{3}$ Departamento de Fitossanidade, UFRGS, Av. Bento Gonçalves, 7712, CEP 91540-000, Porto Alegre, RS \\ Correspondence to: Prof. Luiza Rodrigues Redaelli, Departamento de Fitossanidade, Faculdade de \\ Agronomia, UFRGS, Av. Bento Gonçalves, 7712, CEP 91540-000, Porto Alegre, RS, \\ Brazil, email: luredael@vortex.ufrgs.br \\ Received November 26, 2001 - Accepted March 20, 2002 - Distributed February 28, 2003
}

(With 3 figures)

\begin{abstract}
The oviposition behaviour of Gryon gallardoi (Hymenoptera; Scelionidae) on Spartocera dentiventris (Hemiptera; Coreidae) host eggs was investigated in the laboratory. Masses of 12 non-parasitized freshly laid (less than $24 \mathrm{~h}$ old) eggs were exposed to 2-5 days old mated females with previous oviposition experience $(\mathrm{n}=10)$. Behaviour was observed for $2 \mathrm{~h}$ under the stereomicroscope. The eggs were Then kept individually at $25^{\circ} \pm 1^{\circ} \mathrm{C} / 12 \mathrm{~h}$ photophase till hatching. The mean number of parasitized eggs was $7.8 \pm 0.81(\overline{\mathrm{x}} \pm$ SE). Five distinct kinds of behaviour were observed: drumming with antennae on the eggs, ovipositor insertion, egg marking, walking and resting. On average, ovipositor insertion was not followed by marking $4.3 \pm 0.76$ times per female. In nearly all of these events, parasitism was unsuccessful. Walking and resting were observed less frequently than the other behaviours $(1.6 \pm 0.56$ and $2.1 \pm 0.48$ times/female, respectively). Superparasitism occurred on average $3.6 \pm 0.88$ times per egg mass, with $2.7 \pm 0.57$ eggs being superparasitized. Among these, on average $87.4 \pm 5.37 \%$ led to successful development of an adult parasitoid. The average time spent on the each kind of oviposition behaviour was $1.5 \pm 0.57 \mathrm{~min}$ for drumming, $3.9 \pm 0.56 \mathrm{~min}$ for ovipositor insertion and $0.4 \pm 0.06$ min for marking. There was no significant variation on the duration of each behaviour as the parasitoid progressed in parasitizing an egg mass. Ovipositor insertion almost always $(87.58 \%)$ occurred in the longitudinal extremities of the egg. In average $31.1 \pm 7.21 \%$ of the individual emerging per egg mass were males, the larger proportion of males originating from the $2^{\text {nd }}$ oviposition. The results show a range of oviposition behaviours common to the Scelionidae family. Egg marking behaviour was a good indicator of the effective oviposition by females. Superparasitism is only partially avoided, but its occurrence does not imply a failure of parasitoid emergence. The sex ratio is skewed towards females, and most males come from the first ovipositions.
\end{abstract}

Key words: Insecta, tobacco, gray-tobacco-bug, parasitoid.

\section{RESUMO}

\section{Comportamento de oviposição de Gryon gallardoi (Hymenoptera; Scelionidae) em ovos de Spartocera dentiventris (Hemiptera; Coreidae)}

O presente estudo teve por objetivo investigar, em laboratório, o comportamento de oviposição de Gryon gallardoi (Hymenoptera; Scelionidae) em grupos de ovos de Spartocera dentiventris (Hemiptera; Coreidae). Dez fêmeas, de 2 a 5 dias de idade, fecundadas e com experiência de oviposição, foram expostas a grupos de 12 ovos, não parasitados, com idade de até 24 horas, e observadas durante 2 horas em estereomicroscópio. Posteriormente, os ovos foram mantidos individualizados em estufa a $25^{\circ} \pm$ 
$1^{\circ} \mathrm{C}$, com fotofase de $12 \mathrm{~h}$ até o seu destino final. O número médio de ovos parasitados por grupo foi de 7,8 $\pm 0,81$ ovos ( $\overline{\mathrm{x}} \pm \mathrm{EP}$ ). Registraram-se cinco comportamentos distintos: tamborilamento dos ovos com as antenas, inserção do ovipositor, marcação dos ovos, caminhada e descanso. Em média, por fêmea, $4,3 \pm 0,76$ vezes o comportamento de inserção do ovipositor não foi seguido de marcação. A quase totalidade desses casos resultou no insucesso do parasitoidismo. A caminhada e o descanso foram observados em menor freqüência (1,6 $\pm 0,56$ e 2,1 $\pm 0,48$ vezes/fêmea, respectivamente). $O$ superparasitismo ocorreu em média 3,6 $\pm 0,88$ vezes por grupo de ovos, sendo superparasitados 2,7 $\pm 0,57$ ovos. Destes, em média, $87,5 \pm 5,37 \%$ lograram sucesso na emergência de um adulto. O tempo médio despendido nos principais comportamentos foi de 1,5 $\pm 0,57$ min para tamborilamento, 3,9 $\pm 0,56$ min para inserção do ovipositor e 0,4 $\pm 0,06$ min para marcação, não havendo alteração significativa na duração desses comportamentos ao longo do parasitoidismo da massa de ovos. A inserção do ovipositor foi feita quase sempre na região próxima às extremidades do ovo $(87,58 \%)$. Foi obtida porcentagem média de $31,1 \pm 7,21 \%$ machos/ grupo, sendo que na $2^{\mathrm{a}}$ oviposição originou-se maior proporção de indivíduos machos. Os resultados evidenciam comportamentos de oviposição comuns à família Scelionidae, sendo a marcação dos ovos um bom indicativo de efetiva oviposição da fêmea. O superparasitismo é apenas parcialmente evitado, e sua ocorrência não acarreta o insucesso da emergência de um parasitóide. A razão sexual é desviada para fêmeas, sendo a maioria dos machos gerada nas primeiras oviposições.

Palavras-chave: Insecta, fumo, percevejo-cinzento-do-fumo, parasitóide.

\section{INTRODUCTION}

To assure success in parasitism, a parasitoid needs contact with its host; to accomplish this, it needs to find the host habitat, the host within its habitat and then select the host. When a suitable host is found, the female must oviposit on/in it; in some cases, she may leave a sign on the host, which turns it distinguishable from non-parasitized hosts by herself and also other competing females (van Alphen \& Vet, 1986). Host selection may come through host handling, an important feature of parasitoid behaviour (Godfray, 1994).

A series of distinct kinds of behaviour have been associated with oviposition in parasitoid wasps. Species attacking immobile hosts or host stages spend most of the time examining the host externally, usually touching it with the antennae (drumming) (Godfray, 1994). After host acceptance, the ovipositor is inserted, and then additional information on host quality can be obtained (Godfray, 1994), host growth-inhibiting substances can be inoculated by the female (Strand \& Vinson, 1983), and finally oviposition may proceed. Some parasitoids, as the Scelionidae, mark their hosts after oviposition (Quicke, 1997). According to Colazza et al. (1996), hosts may be marked by chemical secretions or physical change imposed to the host.

In spite of the relevance these various kinds of behviour have for the understanding of foraging patterns and consequently for the parasitism levels observed in nature, little is known about the behaviour of neotropical Hymenoptera.

Egg parasitism is an important mortality factor for the gray-tobacco-bug Spartocera dentiventris (Berg) (Hem.; Coreidae), a species associated with the tobacco culture in Rio Grande do Sul, Brasil (Costa, 1941; Bianco et al., 1998). In experimental tobacco plots parasitism reaches about 50\% (Santos, 1999). Gryon gallardoi Brethes (Hym.; Scelionidae) is the main parasitoid species accounting for this mortality, being a potential biological control agent against this bug.

This study aimed to observe, in the laboratory, the oviposition behaviour of G. gallardoi on egg masses of S. dentiventris, focusing on the different steps of oviposition behaviour and their duration. The occurrence of superparasitism, parasitoid sex ratio per egg mass and per order of oviposition within each egg mass were also assessed.

\section{MATERIAL AND METHODS}

The study was carried out at Departamento de Fitossanidade, Faculdade de Agronomia of the Universidade Federal do Rio Grande do Sul (UFRGS), Porto Alegre ( $30^{\circ} 01^{\prime} \mathrm{S}$ e $\left.51^{\circ} 13^{\prime} \mathrm{O}\right)$, RS, Brazil, from November 2000 to February 2001.

Non-parasitised S. dentiventris eggs were obtained from an experimental tobacco plot 
(Nicotiana tabacum, Virginia type, variety K-326). To avoid parasitism in the field, laying $S$. dentiventris females were kept caged on the plants.

Parasitoids were reared in the laboratory from parasitized $S$. dentiventris eggs collected from tobacco crops at Venâncio Aires $\left(29^{\circ} 60^{\prime} \mathrm{S}\right.$ e $\left.52^{\circ} 19^{\prime} \mathrm{O}\right), \mathrm{RS}$, Brazil. Parasitized eggs and adult parasitoids were kept at $25 \pm 1^{\circ} \mathrm{C} / 12 \mathrm{~h}$ photoperiod. Adults were fed with $10 \%$ honey solution.

Females G. gallardoi used in the experiment were previously mated with males in plastic cages $(19 \times 7 \mathrm{~cm})$. Egg masses were then offered to these females so they could aquire experience in ovipositing before the experiment.

Ten females 2 to 5 days old were used in the experiment. A mass of 12 non-parasitised $S$. dentiventris eggs was offered to each female. They were kept individually in test tubes $(1 \times 6 \mathrm{~cm})$, with a cotton stopper. The eggs were less than $24 \mathrm{~h}$ old and were offered attached to a leaf or shoot section of a tobacco plant as they were laid. Eggs are approximately elliptical. Though here referred to as 'egg mass', usually, eggs are laid apart from each other, longitudinally, in single or double rows on the plant. The number of eggs used in the experiments is the egg mass size mode observed in the field by $S$. dentiventris (Caldas, 1998). Each egg mass was mapped, so that individual eggs could be monitored. From the moment the female first showed interest for the egg masses, her behaviour was then observed for $2 \mathrm{~h}$ on the stereomicroscope under cold light.

The distinct kinds of behaviour observed in the process of oviposition were registered verbally with a tape recorder; from these data, the duration of each behaviour step was measured using a chronometer. The order each egg in the mass was attacked was registered. After observations, eggs were kept individually in gelatine capsules under the same controlled conditions as above up to completion of development. Sex ratios were estimated from both successfully emerged individuals but also failed eggs, which were dissected. Values presented are means \pm SE.

\section{RESULTS}

Five different kinds of female behaviour were observed: drumming, ovipositor insertion, marking, walking and resting. Drumming was characterized by moving the antennae up and down over the exposed surface of the eggs, the female remaining still or walking over the eggs. During drumming, the females did not seem to follow a definite direction, returning to the same egg many times. Subsequently, the female would pause so that the egg was behind her, incline her body and insert the ovipositor in the part of the egg when drumming stopped. From this moment on, she would remain still, with no antennae movement, wings parallel to the body and hind legs firmly holding the attacked egg. After retreating the ovipositor, the female would move backwards, the posterior region of her abdomen swinging laterally, 'brushing' along the surface of the egg, evidencing a marking behaviour.

Walking was characteristic of when there was lack of interest for the eggs by the female, which marched along the test tube or even on top of the eggs but with no drumming. Immobility was characteristic of the resting step, also with immobile antennae, and again either on top of the eggs or at any point of the test tube.

The mean time spent on oviposition (drumming, ovipositor insertion and marking) was $5.5 \pm 0.86$ minutes per egg $(\mathrm{N}=153)$, and $86.7 \pm$ 7.48 minutes per egg mass $(n=10)$ (Table 1$)$. The mean duration of each kind of behaviour is presented on Table 1. Not all females showed the walking and resting steps. Some of them did not walk, others did not rest, and some did not do either. Thus, these behaviours were observed less frequently than the others, that is, $1.5 \pm 0.50$ times per female for walking and $2.0 \pm 0.36$ times per female for resting.

Drumming and ovipositor insertion showed a slight, but not significant, increase in duration as the number of non-parasitised eggs decreased. On the other side, marking duration did not show significant change along the sequence of ovipositions by each female (Fig. 1).

On average, $15.3 \pm 1.23$ ovipositor insertions were observed, per female, $87.58 \%$ of those being on the longitudinal extremity of the eggs $(52.29 \%$ on the operculum and $35.29 \%$ opposite to it), $10.46 \%$ on the median lateral region and only $1.96 \%$ on the top of the eggs. These differences were highly significant both overall (one-way ANOVA, $\mathrm{F}=18.4212$, d.f. $=3,36, \mathrm{p}<0.001$ ), and among themselves, except between the median lateral and top regions. 
TABLE 1

Mean duration, in minutes, of the three steps of oviposition behavior of Gryon gallardoi (Hymenoptera; Scelionidae) on eggs of Spartocera dentiventris (Hemiptera; Coreidae).

\begin{tabular}{|l|c|c|}
\hline \multicolumn{1}{|c|}{ Behavior } & $\begin{array}{c}\text { By egg } \\
(\text { mean } \pm \text { SE) }\end{array}$ & $\begin{array}{c}\text { By egg mass } \\
(\text { mean } \pm \text { SE) }\end{array}$ \\
\hline Drumming & $1.5 \pm 0.57$ & $22.7 \pm 1.49$ \\
\hline Ovipositor-insertion & $3.9 \pm 0.56$ & $60.0 \pm 6.18$ \\
\hline Marking & $0.4 \pm 0.06$ & $4.0 \pm 0.55$ \\
\hline Total & $5.5 \pm 0.86$ & $86.7 \pm 7.48$ \\
\hline
\end{tabular}
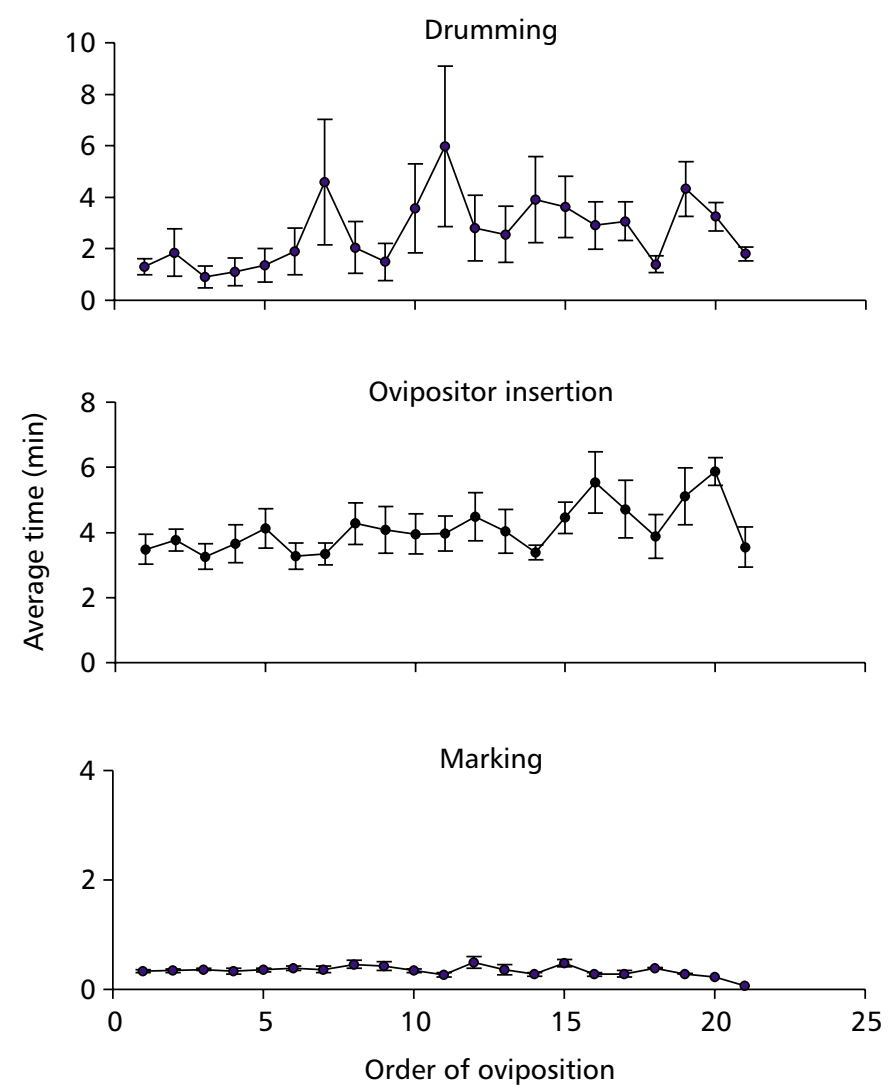

Fig. 1 - Mean duration of drumming behaviour, ovipositor insertion and marking by females of Gryon gallardoi (Hymenoptera; Scelionidae) on Spartocera dentiventris (Hemiptera; Coreidae) egg masses (vertical lines show standard error).

Marking not always followed ovipositor insertion. On average, marking did not occur in $4.3 \pm 0.76 \%$ ovipositor insertions per female. From $78.57 \%$ of the eggs where ovipositor insertion was observed but not followed by marking, nymphs of the host developed. Therefore, marking is an indication of effective parasitism. The mean number of parasitised eggs per mass was $7.5 \pm 0.81$. The sex ratio was female-biased, only $31.1 \pm 7.21 \%$ of the eggs per mass originated males. Males were obtained from any order of oviposition, however they were significantly more frequent from the $2^{\text {nd }}$ egg oviposited by each female on (heterogeneity G-test, $\mathrm{G}_{H}=7.480$; d.f. $=1 ; \mathrm{p}=0.0062$ ) (Fig. 2). 


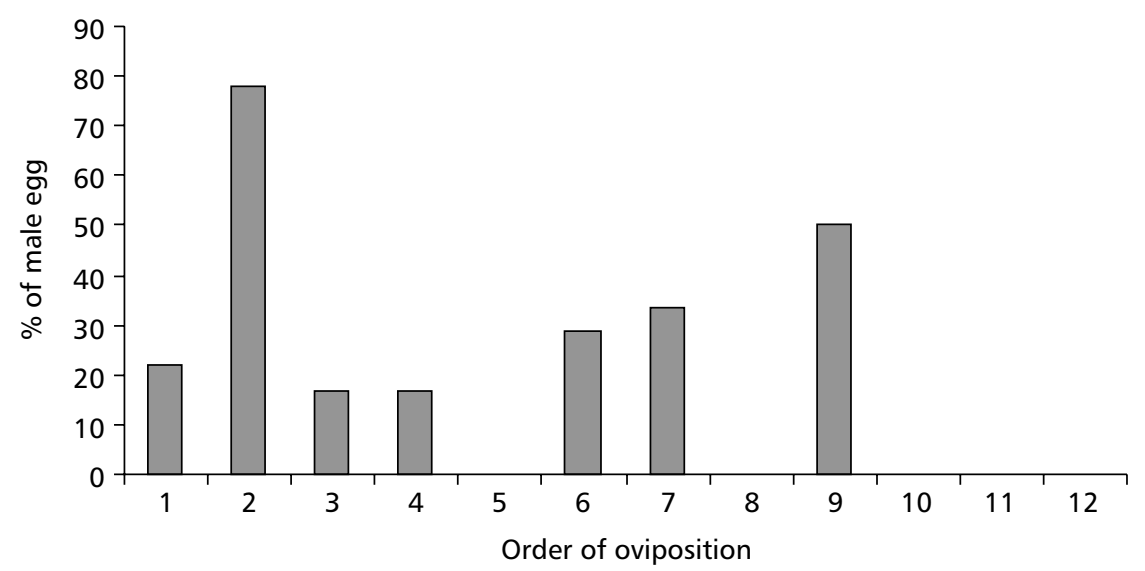

Fig. 2 - Percentage of male eggs oviposited by Gryon gallardoi (Hymenoptera; Scelionidae) females in relation to the order of oviposition on egg masses of Spartocera dentiventris (Hemiptera; Coreidae).

Superparasitism occurred on average $3.6 \pm$ 0.88 times per egg mass, with $2.7 \pm 0.57$ eggs being superparasitised also for each egg mass. Of these, $87.4 \pm 5.37 \%$ successfully gave rise to an adult parasitoid. Superparasitism increases gradually along the parasitoid attack on the egg mass. Most superparasitism occurred from the $10^{\text {th }}$ oviposition on, when the number of non-parasitised eggs was very reduced (Fig. 3).

\section{DISCUSSION}

The behaviour observed for G. gallardoi females (drumming, ovipositor insertion, marking, walking and resting) are common to many species in the Scelionidae family, for example, Asolcus mitsukurii Ashemead, Telenomus nakagawai Watanabe (Hokyo \& Kiritani, 1966), T. sphingis Ashmead (Rabb \& Bradley, 1970), T. heliothidis Ashmead (Strand \& Vinson, 1983) and T. triptus Nixon (Higuchi \& Suzuki, 1996).

The time spent on each kind of behaviour is similar to observations on T. triptus (Higuchi \& Suzuki, 1996).

In this experiment, marking provided a good indication of parasitism. There is lack of information in the literature on the type of marking used by G. gallardoi.

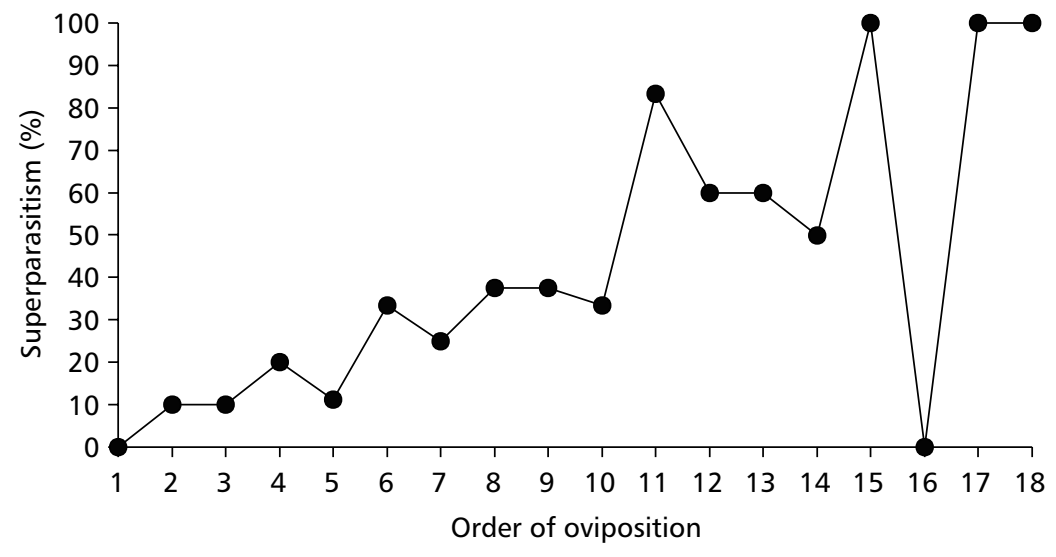

Fig. 3 - Percentage of superparasitism in relation to the order of oviposition by Gryon gallardoi (Hymenoptera; Scelionidae) females on egg masses of Spartocera dentiventris (Hemiptera; Coreidae). 
Chemical marking is effected by a pheromone brushed by the parasitoid ovipositor against the surface of the egg, whilst physical marking comes from protuberances done by parasitoid as it walks on the host (Colazza et al., 1996). Chemical marking is known in the scelionids for T. sphingis e T. heliothidis (Rabb \& Bradley, 1970, and Strand \& Vinson, 1983, respectively). In T. nakagawai and A. mitsukurii, Hokyo \& Kiritani (1966) identified physical marking.

A preference for ovipositor insertion in a specific region - in this case, the operculum - may be part of a strategy to overcome immune responses from the host (Godfray, 1994). The low incidence of ovipositor insertion on the top side of the egg is also known for T. heliothidis, where it was observed on only 5\% of the females (Strand \& Vinson, 1983). Unsuccessful parasitism for eggs in which occurred ovipositor insertion but no marking is also reported for other species of Scelionidae (Hokyo \& Kiritani, 1966; Rabb \& Bradley, 1970; Fedde, 1977; Higuchi $\&$ Suzuki, 1996).

The strategy used for the order of distribution of male eggs is common in solitary parasitoids attacking egg masses in the Scelionidae family: a male egg is usually included in the first ovipositions, followed by a series of female eggs, another male, more females and so on (Waage, 1986). This strategy, besides guaranteeing the presence of at least one male on each egg mass, suggests a simple adaptation mechanism for sexual allocation in egg masses of differing sizes. This "oviposition order" was also observed in the Trichogrammatidae family by Suzuki et al. (1984). On the other hand, Hokyo \& Kiritani (1966) mention that some Scelionidae attacking eggs of Hemiptera and Lepidoptera place a male egg always first. Higuchi \& Suzuki (1996), studying parasitism of T. triptus on eggs of Piezodorus hybneri Gmelin (Hemiptera; Pentatomidae), registered a mean percentage of $15.0 \pm 5.70 \%$ male eggs per egg mass, and that the $1^{\text {st }}, 3^{\text {rd }}$ and $4^{\text {th }}$ ovipositions exceeded $30 \%$ of males.

Superparasitism seems to be partially avoided through the marking behaviour, even though its occurrence does not mean unsuccessful parasitism. Most parasitoids are able to distinguish already parasitised hosts (Rabb \& Bradley, 1970; van Alphen \& Visser, 1990), given that ovipositing on an already parasitised egg reduces offspring quality. There are situations in which superparasitism could be an adaptive reproduction strategy. In the case of solitary parasitoids, having two or more eggs in a host enhances the probability of offspring success if there is competition with other parasitoids. On the other hand, this behaviour may be imposed by the reduction in the number of available eggs and the time involved in searching (van Alphen \& Visser, 1990). According to van Dijken \& Waage (1987), superparasitism acts on the size adjustment and sex ratio of previously oviposited eggs, influencing not only its own success but also that of the others.

Parasitoid emergence rate was lower than the parasitism rate. In a field study, Medeiros et al. (1997) attributed the non-emergence of all parasitoids to the existence of limiting environmental factors. In the present study, developed in a laboratory, this aspect cannot be considered, indicating there are other factors influencing offspring success for the parasitoid, for example, unknown intrinsic factors.

Acknowledgments - We would like to thank Dr. Beatriz S. Correa for help with bibliography and information on parasitoid culturing. We also thank Departamento de Fitossanidade, UFRGS, for providing the necessary infrastructure. Also to Dr. Milton Mendonça Jr. for help with revising and translating.

\section{REFERENCES}

BIANCO, S., GAIAD, J. L. \& OLIVEIRA, G., 1998, Cultura do fumo: manejo integrado de pragas e doenças. Souza Cruz, Santa Cruz do Sul, 44p.

CALDAS, B-H. C., 1998, Ciclo biológico de Corecoris dentiventris Bert, 1884, (Heteroptera, Coreidae) em cultura de fumo e morfologia das fases juvenis. Dissertação de Mestrado, Curso de Pós-graduação em Fitotecnia, UFRGS, Porto Alegre, RS, 93p.

COLAZZA, S., ROSI, M. C., SEBASTIANI, P. \& URSINI, M., 1996, Host acceptance behavior in the egg parasitoid Trissolcus basalis (Hymenoptera: Scelionidae). Acta Oecol., 17(2): 109-125.

COSTA, R. G., 1941, Pragas de plantas cultivadas no Rio Grande do Sul. Secretaria da Agricultura, Porto Alegre, $136 \mathrm{p}$.

FEDDE, G. F., 1977, A laboratory study of egg parasitization capabilities of Telenomus alsophilae. Environ. Entomol., 6(6): 773-776.

GODFRAY, H. C. J., 1994, Parasitoids behavioral and evolutionary ecology. Princeton University Press, Princeton, 473p. 
HIGUCHI, H. \& SUZUKI, Y., 1996, Host handling behavior of the egg parasitoid Telenomus triptus to the egg mass of the stink bug Piezodorus hybneri. Entomol. Exp. Appl., 80: $475-479$.

HOKYO, N. \& KIRITANI, K., 1966, Oviposition behariour of two egg parasites, Asolcus mitsukurii Ashmead and Telenomus nakagawai Watanabe [Hym., Proctotrupoidea, Scelionidae]. Entomophaga, 2: 191-201.

MEDEIROS, M. A., SCHIMIDT, F. V. G., LOIÁCOMO, M. S., CARVAlHO, V. F. \& BORGES, M., 1997, Parasitismo e predação em ovos de Euschistus heros (Fab.) (Heteroptera: Pentatomidae) no Distrito Federal, Brasil. An. Soc. Entomol. Brasil., 26(2): 397-401.

QUICKE, D. L. J., 1997, Parasitic wasps. Chapmann \& Hall, London, 470p.

RABB, R. L. \& BRADLEY, J. R., 1970, Marking host eggs by Telenomus sphingis. Ann. Entomol. Soc. Am., 63(4): 1053-1056

SANTOS, R. S. S., 1999, Mortalidade na fase de ovo de Corecoris dentiventris Bert, 1884 (Heteroptera, Coreidae) em cultura de fumo. Dissertação de Mestrado, Curso de Pósgraduação em Fitotecnia, UFRGS, Porto Alegre, RS, 93p.

STRAND, M. R. \& VINSON, S. B., 1983, Host acceptance behavior of Telenomus heliothidis (Hymenoptera: Scelionidae) toward Heliothis virescens (Lepdoptera: Noctuidae). Ann. Entomol. Soc. Am., 76(4): 781-785.
SUZUKI, Y., TSUJI, H. \& SASAKAWA, M., 1984, Sex allocation and effects of superparasitism on secondary sex ratios in the gregarious parasitoids, Trichogramma chilonis (Hymenoptera: Trichogrammatidae). Anim. Behav., 32: 478-484.

VAN ALPHEN, J. J. M. \& VET, L. E. M., 1986, Evolutionary approach to host finding and selection, pp. 23-61. In: J. Waage \& D. Greathead (eds.), Insect parasitoids. $13^{\mathrm{TH}}$ Symposium of the Royal Entomological Society of London, Academic Press, Inc. London.

VAN ALPHEN, J. J. M. \& VISSER, M. E., 1990, Superparasitism as an adaptive strategy for insect parasitoids. Annu. Rev. Entomol., 35: 59-79.

VAN DIJKEN, M. J. \& WAAGE, J. K., 1987, Self and conspecific superparsitism by the egg parasitoid Trichogramma evanescens. Entomol. Exp. Appl., 43: 183192.

WAAGE, J. K., 1986, Family planning in parasitoids: adaptive patterns of progeny and sex allocation, pp. 6395. In: J. Waage \& D. Greathead (eds.), Insect parasitoids. $13^{\mathrm{TH}}$ Symposium of the Royal Entomological Society of London, Academic Press, Inc., London. 